\title{
TAPHONOMIC BIAS IN FISH DIVERSITY FROM CENOZOIC FLOODPLAIN ENVIRONMENTS
}

\author{
G. R. SMITH, R. F. STEARLEY and C. E. BADGLEY \\ Museum of Paleontology, University of Michigan, Ann Arbor, MI 48109-1079 (U.S.A.)
}

(Received July 21, 1987)

\begin{abstract}
Smith, G. R., Stearley, R. F. and Badgley, C. E., 1988. Taphonomic bias in fish diversity from Cenozoic floodplain environments. Palaeogeogr., Palaeoclimatol., Palaeoecol., 63: 263-273.

The fossil record of Cenozoic floodplain fishes increases from few species in the Paleocene and Eocene to about 5-15 species per locality in the Pliocene and Pleistocene. Modern floodplain habitats usually have more than 5-10 times this many species. The trend could be interpreted as an evolutionary increase, except that there seem to be no ecological or evolutionary reasons to expect ancient floodplains to have fewer species than modern floodplains.

The alternate hypothesis is that ecological and fluvial processes destroy most fish bones before they are finally buried. Although floodplain depositional environments trap many fishes, these are subjected to extensive predation and scavenging, thereby reducing the opportunities for bones of small fishes, which make up most of the diversity, to be preserved in the fossil record. Abrasion in bedload probably destroys most small bones that are reworked. Surface collecting methods exaggerate the bias further because fish bones from fluvial rocks are fragmentary, difficult to discover, and difficult to identify. Screen washing for fossils from fine-grained sedimentary lenses should increase the known diversity from floodplain deposits.
\end{abstract}

\section{Introduction}

There is a large discrepancy in species richness between recent and fossil floodplain fish faunas. Early Cenozoic mammal localities in North American floodplain sediments are typically poor in fossil fishes, except for catfish, gar, and Amia. Late Cenozoic samples are slightly richer in fishes.

By contrast, fish faunas from floodplains of modern rivers are rich in species and higher taxa (Fig.1). Here we test two alternative explanations for the apparent paucity of Cenozoic floodplain fishes by comparing the taxonomy, diversity, habitats, and predator-prey ecology of fossil and Recent fish faunas. The alternative hypotheses are:

(1) North American rivers had few fish species in the early Cenozoic; the rich modern fluvial faunas evolved mostly in the Pliocene and Pleistocene, as indicated by the paleontological record.

(2) The fish-poor floodplain deposits of the early Cenozoic are biased by predator-prey interactions in post-flood depositional habitats and by biased collecting; the faunas were actually rich in species.

Evidence from modern fish diversity suggests that all Cenozoic floodplain faunas must have been richer than the fossil record indicates. If so, taphonomic processes and collecting bias have caused under-representation of fish diversity, especially in the early Cenozoic fossil record. Here we examine various lines of evidence from recent floodplain ecology and taphonomy to choose between the two hy- 


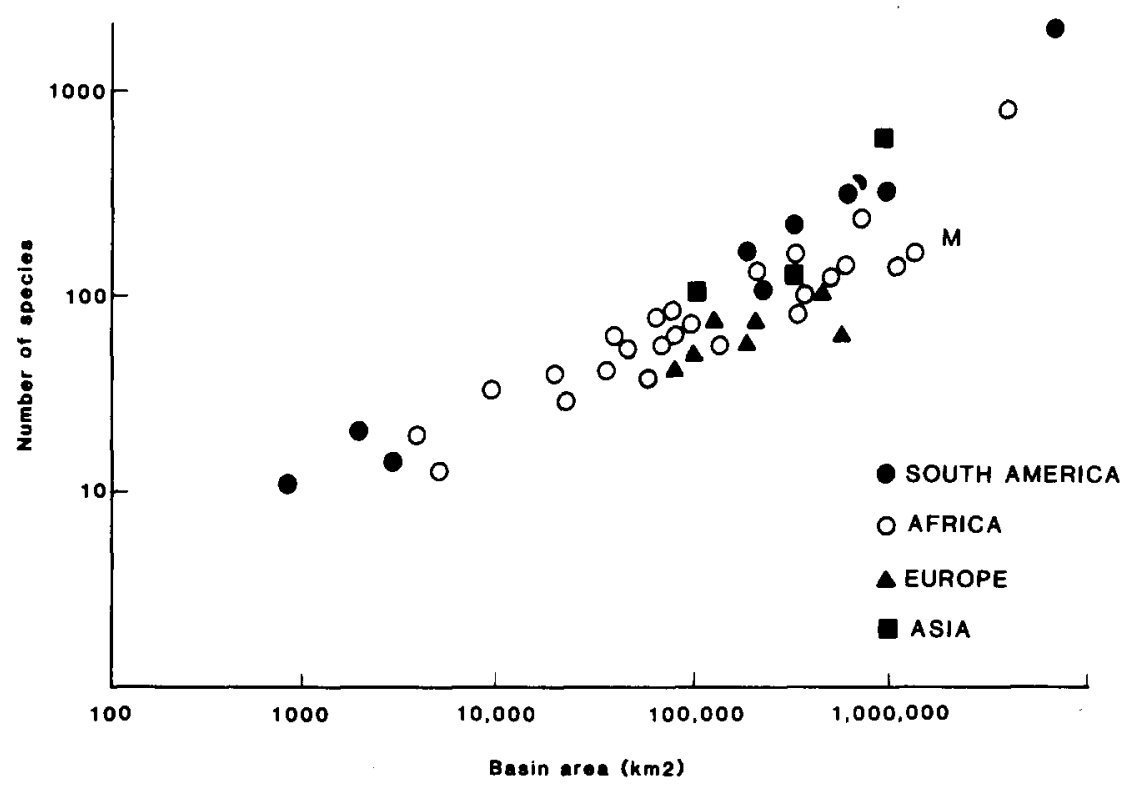

Fig.1. The number of fluvial fish species in river basins, in relation to basin area (after Welcomme, 1979). Examples of small rivers with lowest diversity are (left to right) the Sucio, Paz, Grande S. Tiguel, Me, Boubo, and Bia; large, rich rivers are (in descending order) the Amazon, Zaire, Mekong, Madiera, Orinoco, Parana, Ubangi, Negro, Zambezi, Kasai, and Paraguay. $M=$ Mississippi River.

potheses, and we attempt to identify floodplain environments (microhabitats) that should produce diverse fish faunas, if searched out and collected carefully.

\section{Methods}

Our approach is to compare ecology, taxonomy, and diversity of early Cenozoic, late Cenozoic, and Recent floodplain faunas in light of taphonomic processes. We examine predator-prey relationships, floodplain life-history cycles, floodplain habitats, fish body size, and species differences in bone density as factors related to the likelihood of preservation in different floodplain depositional environments. We also explore the interrelationship of fish diversity in lakes and rivers to evaluate the historical contribution of lacustrine and floodplain interactions to long-term patterns of freshwater fish diversity.

Fossil data for this study come primarily from Cenozoic localities in North America, with limited qualitative observations on some
Miocene fish faunas of Asia. Recent floodplain data are compiled from studies of modern floodplains in North America as well as other temperate and tropical regions. Specific ecological data are drawn from the literature on fish ecology of the lower Mississippi River Valley, which serves as our modern analogue for fossil floodplain depositional environments. Data on the biogeographic relationships between lacustrine fishes and their adjacent floodplain counterparts are drawn from studies of the Laurentian Great Lakes.

\section{Results}

We have suggested two general hypotheses concerning diversity of floodplain fishes in the Cenozoic: (1) that they evolved late, or (2) that they were always abundant but have been taphonomically under-represented in the fossil record. If we, evaluate ecological and taphonomic evidence for and against these ideas, we see indirect support for the taphonomic rather than the evolutionary hypothesis. 


\section{Ecological evidence}

With few exceptions, modern floodplains are rich in fish diversity. Species number is correlated with floodbasin area for modern floodplains over most of the world (Fig.1). Most large temperate and tropical floodplains are also richer than other freshwater environments in diversity at the generic and familial levels. Although floodplain habitats undergo constant seasonal fluctuation, they tend to be stable habitats over millions of years because of the time scale of fluvial and tectonic cycles.

Modern floodplain faunas migrate seasonally between the channels and associated backswamps and lakes. Some of the lakes and swamps are permanent, some ephemeral, but all are connected and recolonized with the yearly flood cycle. Today, almost all freshwater fish diversity is primarily dependent on a rich, floodplain-adapted species pool, which serves as a recolonization source following local extinctions (Horowitz, 1978). Stated another way, floodplain habitats around the world are typically the stable centers of fish diversity for river drainages. Fish faunas associated with permanent rivers and their associated floodplain lakes are almost always as rich or richer in species than lakes or channels in the headwaters of the same system (the exceptions are species flocks in old, stable lakes in rift zones).

There is no ecological reason to expect that early Cenozoic floodplains would have been less favorable to the coexistence of abundant fish species, unless the rivers were exposed to extreme fluctuations in temperature or desiccation, causing repeated extinction of fish populations and consequent reduction of diversity (Horowitz, 1978). But Paleocene and Eocene climates of North America are thought to have been subject to lower seasonal fluctuations in temperature than those of the Neogene (MacGinitie, 1969; Wolfe, 1978). Postulated playa lake cycles for the Eocene Green River drainage system (Eugster and Surdam, 1973; Eugster and Hardie, 1975; Boyer, 1982; Sullivan, 1985) would not have eliminated flood- plain fishes more drastically than lake species in the long term. Early Cenozoic lakes were rich in fish diversity (Wilson, 1977; Grande, 1984). Most early Cenozoic lake species would have been at least as successful in fluvialfloodplain habitats, as are many modern species found in both habitats.

Large-river floodplain habitats such as that of the Mississippi River should have contained diverse faunas wherever they had long, stable Cenozoic histories. Even if modified geographically by changes in fluvial cycles and drainage shifts, or locally deprived of volume by aridity as in the high plains of the Mississippi drainage, the fish habitats and faunas of depositional areas at the edge of large cratonic areas should have enjoyed long-term continuity. Evidence for this phenomenon exists in the localization of the Cenozoic holdovers of Mesozoic freshwater groups (gars, Amia, sturgeons, paddlefish, lungfish, bichirs) in scattered floodplain habitats throughout the world, indicating long-term stability and low extinction rates for floodplain inhabitants.

Large rivers typically possess floodplains with associated lakes that are permanent, at least over hundreds to thousands of years (Russell-Hunter, 1978). These lakes are part of the refuges against extinction of floodplain fishes. Lakes in a river system usually contain many of the floodplain fishes because the floodplain was their biogeographic source and because shallow lacustrine and floodplain environments have similar microhabitats (Welcomme, 1979). Except for old rift lakes with endemic faunas, lakes usually have a small subset of the floodplain fauna, with additional endemic taxa coincident with their ages or with other factors contributing to speciation processes (Echelle and Kornfield, 1984). For example, the major tributaries to the Laurentian Great Lakes (Bailey and Smith, 1981) usually have $18-39 \%$ more species than the lakes themselves (Table I). In fact, only about 17 of the 159 native species can be considered predominantly lake forms and only 64 species are usual inhabitants of larger lakes. About 90 of the species listed for the Great Lakes by 
TABLE I

Survey of native species of fishes from the Laurentian Great Lakes and their tributaries (from Bailey and Smith, 1981)

\begin{tabular}{llccl}
\hline Lake & $\begin{array}{l}\text { Number of species } \\
\text { in drainage }\end{array}$ & $\begin{array}{l}\text { Number of species } \\
\text { in tributaries }\end{array}$ & $\begin{array}{l}\text { Number of species } \\
\text { in lake }\end{array}$ & $\begin{array}{l}\text { Number of } \\
\text { species common } \\
\text { in lake }\end{array}$ \\
\hline Superior & 75 & 70 & 43 & 42 \\
Michigan & 126 & 119 & 79 & 60 \\
Huron & 107 & 99 & 76 & 59 \\
Erie & 116 & 107 & 91 & 50 \\
Ontario & 119 & 113 & 85 & 58 \\
Total & 159 & 147 & 113 & 64 \\
\hline
\end{tabular}

Bailey and Smith are primarily fluvial-floodplain inhabitants that find utilizable microhabitats in the littoral zone of the Great Lakes. Fish diversity in geologically young systems like the Great Lakes is the result of colonization from more ancient fluvial refugia.

Floodplains can be extraordinarily productive aquatic systems (Welcomme, 1979; Moss, 1980; Pennington et al., 1983). A Louisiana study of seven floodplain lakes (Table II) showed an average standing crop of fishes of $180 \mathrm{~kg} / \mathrm{ha}$ (397 lbs/acre; Lambou, 1959). The range, which was not unusual for floodplains (Welcomme, 1979; Guillory, 1979), was 26$179 \mathrm{~kg} / \mathrm{ha}$ (142-974 lbs/acre). Sampling was conducted in the backwater lakes following the flood season. Predators made up $44 \%$ of the total fish biomass, averaging $31 \mathrm{~kg} / \mathrm{ha}(167$ lbs/acre). The fauna of this floodplain area contains over 70 species, representing more than 30 genera and 13 families.

The stability of fluvial-floodplain habitats over geological time $\left(10^{5}-10^{6} \mathrm{yr}\right)$ despite geologically short-term changes in water levels, geographic positions, and connections, makes the diverse floodplain-adapted species pool a general fact of significance to interpretation of Cenozoic diversity. There is no ecological reason to postulate an early Cenozoic exception to the empirical generalization of high floodplain diversity, biomass, and longevity, as long as the main rivers were permanent, i.e.,

\section{TABLE II}

Survey of fishes of the Lower Mississippi River floodplain and seven Louisiana Lakes (floodplain lake data from Lambou, 1959; general data from Cook, 1959; Douglas, 1974; Guillory, 1979; Lee et al., 1980)

\begin{tabular}{|c|c|c|c|c|c|c|}
\hline \multicolumn{4}{|c|}{ Floodplain species, Lower Mississippi } & \multicolumn{3}{|c|}{7 Louisiana floodplain lakes } \\
\hline Fish group & $\begin{array}{l}\text { Number of } \\
\text { species }\end{array}$ & $\%$ of Total & $\begin{array}{l}\text { Number of } \\
\text { species expected } \\
\text { as fossils }\end{array}$ & $\begin{array}{l}\text { Number of } \\
\text { species }\end{array}$ & $\begin{array}{l}\% \text { of Total } \\
\text { weight }\end{array}$ & $\begin{array}{l}\text { Approx. adult } \\
\text { size }(\mathrm{cm})\end{array}$ \\
\hline Gar, Amia & 5 & 4 & 5 & 5 & 21 & $40-100$ \\
\hline Catfish & 7 & 6 & 7 & $\mathbf{5}$ & 8 & $15-80$ \\
\hline Large piscivor. & 15 & 13 & 15 & 9 & 15 & $10-80$ \\
\hline Herring & 4 & 3 & 0 & 3 & 25 & $12-25$ \\
\hline Microvores & 75 & 63 & 10 & & & $4-25$ \\
\hline Suckers & 9 & 8 & 9 & 51 & 26 & $25-50$ \\
\hline $\begin{array}{l}\text { Sharks, Sturgeon, } \\
\text { Paddlefish }\end{array}$ & $\mathbf{5}$ & 4 & 4 & & & $50-100$ \\
\hline
\end{tabular}


not seasonally desiccated. Therefore, we conclude that early Cenozoic floodplain systems with associated lakes, such as in the Eocene of Wyoming, should have had diversity comparable to that in the nearby lakes.

\section{Paleontological evidence}

Contrary to the above considerations based on recent fish ecology, the paleontological record as now understood favors the hypothesis that floodplain fish diversity was low early in the Cenozoic and evolved late in the Cenozoic, reaching its observed high modern levels only recently. For example, preliminary examination of several thousand fish bone fragments from early Miocene floodplain sediments of Pakistan (Pilbeam et al., 1979) reveals low diversity, except in a few screen-washed microvertebrate samples that contain more than a dozen discriminated (but not identified) taxa. Most of the samples are dominated by catfish, with cyprinids, ophicephalids, and occasional perciformes making up the rest of the fauna. Related rocks from Nepal also contained only a few recognizable catfish, cyprinids, and ophicephalids (Munthe et al., 1983).

North American Paleogene floodplain fish samples, mostly from mammal localities, contain an average of about five and a maximum of eight kinds of fishes. (Recognizable taxa are always an underestimate of actual species, but the estimate deficiency - possibly up to $33 \%$ - is not enough to explain the observed discrepancy between expected and observed fossil species.) Neogene samples from North American mammal localities contain more fish species (on average, about eight) than early Cenozoic samples (Table III). In general, floodplain deposits rarely produce more than a dozen fish species.

The apparent number of species in Cenozoic samples is correlated with age. The rich fluvial fish faunas from the Pliocene and Pleistocene of the Great Plains contain modern genera usually unknown before late Miocene or Pliocene time, indicating late Cenozoic evolution of the genera making up the modern diversity (Smith, 1981). Early Cenozoic floodplain faunas, in addition to being sparse, are dominated by gar (Lepisosteus), bowfin (Amia), and extinct catfish (Table III; Lundberg, 1975). Gar and Amia, as already mentioned, are Cenozoic remnants of Mesozoic groups, thus providing some support for the idea that the present diversity is a later evolutionary development.

The actual contrast between Paleogene and Neogene floodplain faunas may not be as sharp as suggested above. Review of the literature for the Eocene Green River lakes (Green River Formation) and their surrounding fluvial facies (Wasatch, Bridger, and correlated formations) hints at a broader fish diversity for the nearby rivers. More catfish species are presently recorded from the fluvial facies than from the lakes (Lundberg, 1975; Grande, 1984). Isolated records of the genera Priscacara, Phareodus, Mioplossus, Notogoneus, and a paddlefish have all been located in fluvial sediments associated with the Green River lakes (McGrew, 1971; Grande, 1984). McGrew (1971) lists Phareodus, an osteoglossid predator, as "common" in such sediments. Nevertheless their discovery has been too infrequent to affect significantly the diversity observed at any single locality. It is noteworthy that this list is restricted to forms with rather large or dense jaw or pharyngeal bones. It is possible that most of the other lake taxa (e.g., Knightia and Diplomystus) also inhabited the tributary floodplains, but that their small size and delicate bones make them extremely rare and difficult to discover. Because most fish bones are fragile and apparently destroyed by fluvial processes, it is likely that the small size and abraded or fragmentary condition of these fossils lead most collectors to fail to identify them as interesting or important.

In summary, although the fossil record shows few species, especially further back in time, there are ecological and paleontological reasons for suspecting that the Cenozoic floodplain fish record is biased toward underrepresentation of original fish diversity. If greater Cenozoic floodplain species richness 
TABLE III

Summary, by habitat, of North American freshwater fish faunas from the Cenozoic (based on 51 faunas; most citations listed in Smith, 1981)

\begin{tabular}{|c|c|c|c|c|c|}
\hline Fauna & Age & Number of kinds & Gar & Amia & Catfish \\
\hline \multicolumn{6}{|l|}{ Floodplain } \\
\hline Willwood & Eocene & 4 & 1 & 1 & 1 \\
\hline Bridger & Eocene & 8 & 1 & 1 & 2 \\
\hline Slim Buttes & Eoc/Olig & 2 & 1 & & 1 \\
\hline Wessington & Miocene & 1 & & & 1 \\
\hline Verdigre & Miocene & 6 & 1 & 1 & 2 \\
\hline Red Light & Pliocene & 3 & & & 2 \\
\hline Hagerman & Pliocene & 12 & & & 1 \\
\hline McPherson & Pleistocene & 4 & 1 & & 1 \\
\hline Mt. Scott (a) & Pleistocene & 10 & 1 & & 2 \\
\hline \multicolumn{6}{|c|}{ Backwater lake on floodplain } \\
\hline Ochoco Pass & Oligocene & 4 & & 1 & 1 \\
\hline WaKeeny & Miocene & 10 & 1 & 1 & 1 \\
\hline Sand Draw & Pliocene & 9 & 1 & & 1 \\
\hline Kanopolis & Pleistocene & 10 & 1 & & 1 \\
\hline Butler Spring & Pleistocene & 6 & 2 & & 1 \\
\hline McCormick & Pleistocene & 2 & & & \\
\hline Mt. Scott (b) & Pleistocene & 14 & 1 & & 1 \\
\hline \multicolumn{6}{|c|}{$\begin{array}{l}\text { Total number of kinds, averaged for environments, from above faunas } \\
\text { (Percentages across rows in parentheses) }\end{array}$} \\
\hline & $\begin{array}{l}\text { large } \\
\text { piscivore }\end{array}$ & microvores & $\operatorname{ar}+A m i a$ & catfish & misc. \\
\hline Floodplain & $0.8(16)$ & $1.6(32)$ & $.9(18)$ & $1.3(26)$ & $0.4(8)$ \\
\hline Flood lake & $1.1(14)$ & $4.9(58)$ & $.1(14)$ & $1.3(14)$ & \\
\hline Channel & $0.5(6)$ & $6.5(72)$ & $.5(6)$ & $1.5(16)$ & \\
\hline Lake, margin & $1.8(15)$ & $7.0(60)$ & $.0(9)$ & $0.8(6)$ & $1.1(10)$ \\
\hline Lake, deep & $1.2(16)$ & $4.1(60)$ & $8(12)$ & $0.8(12)$ & \\
\hline
\end{tabular}

was a reality, we must explain the causes of bias and suggest collection methods that will reveal the suspected fish diversity.

\section{Causes of taphonomic bias in floodplain fish faunas}

The annual flood cycle of large, non-impounded rivers involves not only large changes in water volume, but $2-20 \times$ fluctuations in areal coverage (Welcomme, 1979). In the United States, the 100-year flood area is estimated to be about $6 \%$ of the total land area (Sabol, 1974). The flood period (or periods) may cover one-tenth to one-half the year. The life cycles of floodplain fishes follow the flood cycle closely, the flood period being a time of reproduction and maximum growth for most fishes inhabiting large temperate and tropical rivers (Lowe-McConnell, 1975, p. 90, 1977, p. 47).

Lowe-McConnell $(1975,1977)$ has shown that the cycle of floodplain inundation and desiccation is closely tracked by fish spawning migration and predator-prey relationships, and we suggest that this occurs in a way that could consistently remove fossil evidence of most of the original fish diversity. The suggested mechanisms of removal are migration as water levels begin to fall, and predation and scaveng- 


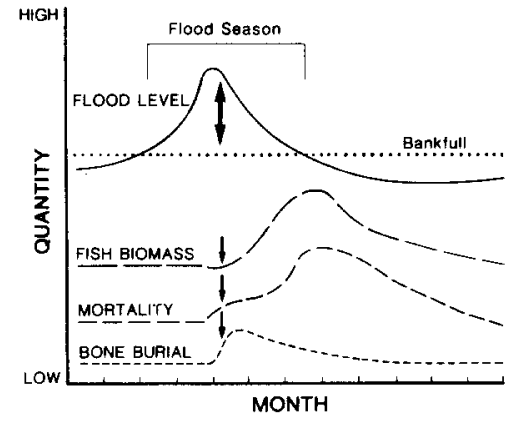

Fig.2. The likelihood of fish bone burial in floodplain sediments is a function of the timing of fish abundance and mode of mortality in relation to the annual inundation and desiccation cycle. Burial (or reburial) occurs during maximum sediment deposition (arrow). Note relation to the periods of maximum fish biomass and mortality. The maximum sediment pulse may bury fishes that died during spawning (provided that they are not floating) and any bones from the previous year's mortality that escaped digestion and chemical dissolution.

ing after receding water levels leave the floodplain lakes and back swamps isolated from the main channels (Fig.2).

Massive reproduction and early growth of fish in floodplain habitats creates a preferred feeding habitat for their piscivorous predators (Lowe-McConnell, 1975, 1977). Therefore, predators may cause considerable non-fossilizable mortality until the latest stages of formation of a death assemblage. [This assumes that few fish bones are sufficiently robust to survive digestion; the exceptions may be recognizable and informative fossils (Fisher, 1981).] In the last stages of desiccation of temporary floodplain ponds, large predators and scavengers, but few small fishes, may remain to be fossilized. If smaller fishes have been trapped by rapid desiccation, and buried by immediate reflooding and silt deposition (before removal by terrestrial scavengers), they are apparently not often discovered or recovered as fossils.

The above arguments imply that the fossil record of floodplain fishes may be biased by ecological and taphonomic processes. It is the small, thin-boned, non-predaceous, and nonscavenging species that are under-represented. Following is a summary of ecological and taphonomic factors contributing to this bias.

\section{Predator-prey relationships}

Lowland floodplain fossil fish assemblages are dominated by gar, Amia, and catfishes which are large predators or scavengers, usually with large, identifiable teeth and bones. These species remain longer in temporary ponds, as they forage on the smaller fishes trapped with them. Other large fish with large teeth, either piscivores or mollusk crushers, also can appear disproportionately in floodplain samples, because their larger, harder bones and teeth can resist digestion and abrasion.

\section{Physiology}

Gars, Amia, catfish, and some other ostariophysan fishes have accessory breathing adaptations and high heat tolerance, and therefore survive longer in impounded backwaters following flood peaks (Fig.2). Once isolated, these waters become warmer, increasingly stagnant, and acidic as their oxygen is depleted by decomposition and the lower oxygen saturation levels of warmer waters. Under these conditions, predators and scavengers, particularly diverse kinds of catfish, are especially successful (Bailey, 1955). Fishes that succumb to heat stress or anoxia will be scavenged, and only digestion-resistant bones and teeth will enter the fossil record. In South America, Hoplias and Erythrinus, and in south Asia, Ophicephalus, parallel Amia in these physiological and ecological characteristics. They are large, heavy boned, long-lived predators and scavengers.

\section{Bone density}

Many benthic or semi-benthic inhabitants of large flowing waters have massive, dense bones and sometimes spines. Catfish, suckers, gar, Amia, and Amia-parallels possess such heavy bones. The bone density is often constructed of distinctive ridges and tubercles, and such species are easily identified thereby. The bias here operates on three levels - habitat specifi- 
city of the heavy-boned fishes, persistence of the bone despite abrasion, digestion, or acidic destruction, and taxonomic distinctiveness.

\section{Elevation}

Floodplain faunas at altitudes higher than those in which gar and Amia persist are less diverse than lowland faunas (Smith and Lundberg, 1972). Medium-altitude floodplain faunas are dominated by catfish and other ostariophysans, with occasional perciforms. The best example in the North American Cenozoic record is the Hagerman floodplain fauna in the Pliocene of Idaho, with 12 species consisting mostly of large ostariophysans - catfish, suckers, and large cyprinids (Smith et al., 1982). Despite this apparent richness (Table III) adjacent lake deposits had twice as many recorded species, suggesting that the floodplain diversity should have been much greater. Thus, taphonomic bias against preserved fish diversity is intensified at higher elevations because of smaller habitats and smaller fishes, less floodplain deposition, and absence of gar and Amia.

\section{Collection bias and fluvial fossil fishes}

It is possible that the limited diversity of fossil fishes known from fluvial deposits derives in part from collection bias. Fluvial sediments do not attract fish paleontologists because of the expected lack of fish diversity relative to lake beds and certain marine facies. Fluvial beds are studied especially by mammalian paleontologists who may understandably bias their collection efforts according to their own research priorities. Fish are often unrecognized and uncollected in these circumstances.

The effect of this source of bias was investigated by comparing two collections from an Eocene floodplain locality in the Clarks Fork Basin, Wyoming. The Clarks Fork Basin, located in the northwest corner of the Bighorn Basin, is best known for its Paleocene and Eocene mammalian faunas. Remains of verte- brates at UMMP Locality SC-213 (P.D. Gingerich, pers. comm., 1986) were collected from the surface of naturally weathered outcrops by University of Michigan field parties during four field seasons. The surface collecting procedures emphasized mammalian dental, gnathic, and cranial remains, well-preserved post-cranials, and distinctive non-mammalian remains. Table IVa demonstrates the ratio of fish remains to catalogued mammalian remains in each of four collections. Three fish taxa were recovered.

A second procedure, initiated at this particular locality by Badgley and co-workers during two later field seasons, attempted recovery of all skeletal material on the surface. Table IVb shows the increased representation of fish bones; four fish taxa were recovered.

The effect of collection bias on the faunas summarized in Table III is difficult to evaluate without additional comparative studies, but it is possible that part of the richer record of floodplain fish species in late Cenozoic collections in North America is a reflection of the collecting methods (screen washing) and special attention to fish by Claude W. Hibbard and his students in Kansas, Oklahoma, Nebraska, and Idaho (Hibbard and Taylor, 1960; Smith and Lundberg, 1972). The faunas collected by Hibbard average over 8 taxa per fauna $(N=9)$; others of the same age average 3.5 taxa per fauna $(N=8)$. The difference is largely attributable to the success of screen washing, but exceptions include one rich fauna obtained by surface collecting (Hagerman, Idaho) and occasional screen-washed samples that have few fish.

\section{Future studies of floodplain fish diversity}

Demonstrated fish paucity in taphonomically unbiased early Cenozoic floodplain settings would refute the hypothesis of greater floodplain species diversity in the early Cenozoic. Evidence for lack of taphonomic bias would consist of lenses representing flooded and buried temporary ponds with well-preserved small fish fossils but with few species, 
TABLE IV

Fish diversity in fossil samples from different collection strategies, UMMP Locality 213, Willwood Formation, Clarks Fork Basin, Wyoming

\begin{tabular}{lllll}
\hline Year & $\begin{array}{l}\text { Number of } \\
\text { catalogued } \\
\text { mammal jaws }\end{array}$ & $\begin{array}{l}\text { Number of } \\
\text { fish } \\
\text { remains }\end{array}$ & $\begin{array}{l}\text { Ratio } \\
\text { fish/mamm. }\end{array}$ & $\begin{array}{l}\text { Number of } \\
\text { fish taxa }\end{array}$ \\
\hline
\end{tabular}

$\begin{array}{lrccl}\text { (a) Selective collection oriented to mammalian remains } \\ 1978 & 226 & 8 & 0.04 & 2 \text { Amia, gar } \\ 1980 & 30 & 2 & 0.07 & 1 ? \\ 1982 & 164 & 2 & 0.01 & 1 \text { Priscacara } \\ 1983 & 57 & 3 & 0.05 & 2 \text { Amia, gar } \\ & & & & 3 \text { total }\end{array}$

(b) Collection of all surface skeletal material, four levels, 1984-1985

Strat. level

\begin{tabular}{lrrrl}
$\mathrm{a}_{0}$ & 5 & 21 & 4.2 & 2 gar, catfish \\
$\mathrm{a}$ & 13 & 38 & 2.9 & 3 Amia, gar, \\
& & & & Priscacara \\
$\mathrm{b}$ & 64 & 3 & 0.05 & 1 gar \\
$\mathrm{c}$ & 9 & 1 & 0.11 & 1 Amia \\
& & & 4 total \\
\hline
\end{tabular}

along with collections from associated floodplain, channel, point bar, and oxbow deposits, with the same few species. That the low diversity was not due to local isolation, low equability, or seasonal aridity could be tested through normal paleoecological habitat and climatic reconstruction (e.g. Hibbard and Taylor, 1960). Attention to spatially-restricted, fine-grained floodplain facies seems to be the key to this testing program.

We note that three kinds of modern fluvial habitats produce diversity of fishes and other fossil vertebrates. These are very different as habitats for living fishes and their ancient sedimentary facies should be studied as possible environments for deposition of fish bones.

\section{Lotic fluvial}

This environment, represented especially by channel deposits, should preserve isolated large, dense bones of ganoids (gars and Amia) and benthic teleosts, mostly catfishes, in addition to fossil mammals. Any fossil fish bones from this habitat must have survived digestion and abrasive transport. Small, delicate bones of small fishes typically abundant in rivers are probably preferentially eliminated by crushing, abrasion, and chemical dissolution. Those bones that persist are extremely difficult to find and collect because bone size is frequently smaller than clast size. Since most of the diversity is in small fishes, most is taphonomically underrepresented in the fossil record. Although attempts to find small bones in these sediments should be pursued, future studies may not change this bias appreciably.

\section{Relatively permanent, flood-connected backswamps and ox-bow lakes}

Bones of larger predators and scavengers, including gars, Amia, catfish, turtles, and crocodilians are often abundant in this depositional habitat. Remains of small forms are rare, and we suspect that the vast majority of them are deleted by predation and scavenging. Those that remain will usually be found only by specialized collection methods such as screen washing. 


\section{Temporary back swamps and sloughs}

Fishes trapped and desiccated before predation must be buried before scavenging, to be preserved. Important taphonomic variables are timing of desiccation, sedimentation, and erosion. This environment will appear as thin, spatially limited lenses, and should preserve smaller, more delicate-boned fishes, if searched for and screen-washed. The unusually rich Mt. Scott fauna (14 species) of the Pleistocene of Meade County, Kansas (Smith, 1963) is possibly an example of this environment of deposition. Selective attention to this environment of deposition should provide a test of fish diversity in floodplain environments.

\section{Summary}

Ecologic factors influencing real and apparent fish diversity in the Cenozoic fossil record include spawning migrations and reproductive cycles related to flood seasonality, predation and scavenging of small fishes in ponded temporary waters, and fish sensitivity to heat stress and anoxia. We propose that these biological factors contribute to taphonomic bias favoring gars, Amia, and catfishes in North American Cenozoic floodplain sediments at the expense of diverse smaller fishes. Percoid predators may also be important, especially in later Cenozoic deposits. Gars, Amia, and catfishes tend to be the last survivors in temporary floodplain habitats because they are predators and have air-breathing adaptations, because they are migratory into such habitats for reproduction, and because as benthic fishes they have massive, distinctive bones, scales, or spines; percoids often have dense jaws or pharyngeal teeth.

Taphonomic factors contributing to underrepresentation of Cenozoic fish diversity include selective destruction of small fish bones (which represent the vast majority of the diversity) by predation, fluvial abrasion, and acidic dissolution. Environments that are desiccated early and buried by silt before scavenging by terrestrial vertebrates could pro- duce evidence of greater fish diversity. Search for these sedimentary units and careful screenwashing for small vertebrate fossils would allow a test of the hypothesis that fish diversity in the Cenozoic fossil record is a consequence of taphonomic and collecting bias rather than true low diversity prior to the Pliocene and Pleistocene.

\section{References}

Bailey, R. M., 1955. Differential mortality from high temperature in a mixed population of fishes in southern Michigan. Ecology, 36(3): 526-528.

Bailey, R. M. and Smith, G. R., 1981. Origin and geography of the fish fauna of the Laurentian Great Lakes basin. Can. J. Fish. Aquat. Sci., 38(12): 1539-1561.

Boyer, B. W., 1982. Green River laminites: Does the playalake model really invalidate the stratified lake model? Geology, 10: 321-324.

Cook, F. A., 1959. Freshwater fishes in Mississippi. Miss. Game Fish Comm., Jackson, 239 pp.

Douglas, N. H., 1974. Freshwater Fishes of Louisiana. Claitor, Baton Rouge, 443 pp.

Echelle, A. A. and Kornfield, I., 1984. Evolution of Fish Species Flocks. Univ. Maine, Orono, $257 \mathrm{pp.}$

Eugster, H. P. and Hardie, L. A., 1975. Sedimentation in an ancient playa-lake complex: The Wilkins Peak Member of the Green River Formation of Wyoming. Geol. Soc. Am. Bull., 86: 319-334.

Eugster, H. P. and Surdam, R. C., 1973. Depositional environment of the Green River Formation of Wyoming: A preliminary report. Geol. Soc. Am. Bull., 84: 1115-1120.

Fisher, D. C., 1981. Taphonomic interpretation of enamelless teeth in the shotgun local fauna (Paleocene, Wyoming). Univ. Mich. Mus. Paleontol. Contrib., 25(13): 259-275.

Guillory, V., 1979. Utilization of an inundated floodplain by Mississippi River fishes. Fla. Sci., 42: 222-228.

Grande, L., 1984. Paleontology of the Green River Formation, with a review of the fish fauna. Geol. Surv. Wyo. Bull., 63: 1-333.

Hibbard, C. W. and Taylor, D. W., 1960. Two late Pleistocene faunas from southwestern Kansas. Univ. Mich. Mus. Paleontol. Contrib., 16: 1-223.

Horowitz, R. L., 1978. Temporal variability patterns and the distributional patterns of stream fishes. Ecol. Monogr., 48: 307-321.

Lambou, V. W., 1959. Fish populations of backwater lakes in Louisiana. Trans. Am. Fish. Soc., 88: 7-15.

Lee, D. S., Gilbert, C. R., Hocutt, C. H., Jenkins, R. E., McAllister, D. E. and Stauffer, Jr., J. R., 1980. Atlas of North American Freshwater Fishes. North Carolina State Museum Nat. Hist., Raleigh, 854 pp.

Lowe-McConnell, R. H., 1975. Fish Communities in Tropical Fresh Waters. Longman, London, 337 pp. 
Lowe-McConnell, R. H., 1977. Ecology of Fishes in Tropical Waters. Edward Arnold, London, $65 \mathrm{pp}$.

Lundberg, J. G., 1975. The fossil catfishes of North America. Univ. Mich. Mus. Paleontol. Pap. Paleontol., 11: $1-51$.

MacGinitie, H. D., 1969. The Eocene Green River flora of northwestern Colorado and northeastern Utah. Univ. Calif. Publ. Geol. Sci., 83: 1-140.

McGrew, P. O., 1971. Early and Middle Eocene faunas of the Green River Basin. Univ. Wyo. Contrib. Geol., 10: 65-68.

Moss, B., 1980. Ecology of Fresh waters. Wiley, New York, N.Y., 332 pp.

Munthe, J., Dongol, B., Hutchison, J. H., Kean, W. F., Munthe, K. and West, R. M., 1983. New fossil discoveries from the Miocene of Nepal include a hominoid. Nature, 303: 331-333.

Pennington, C. H., Baker, J. A. and Potter, M. E., 1983. Fish populations along natural revetted banks on the lower Mississippi River. North Am. J. Fish. Manage., 3: 204-211.

Pilbeam, D. R., Behrensmeyer, A. K., Barry, J.C. and Shah, S. M. I., 1979. Miocene sediments and faunas of Pakistan. Postilla, 179: 1-45.

Russell-Hunter, W. D., 1978. Ecology of freshwater pulmonates. In: V. Fretter and J. Peale (Editors), Pulmonates. Academic Press, New York, N.Y., 12A, pp. $335-383$.

Sabol, K. J., 1974. National Conference on Floodplain
Management. Natl. Assoc. Conserv. Districts, League City, Tex., $261 \mathrm{pp}$.

Smith, G. R., 1963. A late Illinoian fauna from southwestern Kansas and its climatic significance. Copeia, 1963: $278-285$.

Smith, G. R., 1981. Late Cenozoic freshwater fishes of North America. Annu. Rev. Ecol. Syst., 12: 163-193.

Smith, G. R. and Lundberg, J. G., 1972. The Sand Draw fish fauna. In: M. F. Skinner and C. W. Hibbard (Editors), Early Pleistocene Preglacial and Glacial Rocks and Faunas of North-Central Nebraska. Am. Mus. Nat. Hist. Bull., 148(1): 40-54.

Smith, G. R., Swirydczuk, K., Kimmel, P. G. and Wilkinson, B. H., 1982. Fish biostratigraphy of Late Miocene to Pleistocene sediments of the western Snake River Plain, Idaho. In: B. Bonnichsen and R. M. Breckenridge (Editors), Cenozoic Geology of Idaho. Idaho Bur. Mines Geol. Bull., 26: 519-541.

Sullivan, R., 1985. Origin of lacustrine rocks of the Wilkins Peak Member, Wyoming. Am. Assoc. Pet. Geol. Bull., 69: 913-922.

Welcomme, R. L., 1979. Fisheries Ecology of Floodplain Rivers. Longman, London, $317 \mathrm{pp.}$

Wilson, M. V. W., 1977. Middle Eocene Freshwater fishes from British Columbia. R. Ont. Mus. Life Sci. Contrib., 113: $1-61$.

Wolfe, J. A., 1978. A paleobotanical interpretation of Tertiary climates in the Northern Hemisphere. Am. Sci., 66: 694-703. 